\title{
The Oldest Anaesthesiologist on the Balkan Peninsula, Dr. Risto Ivanovski, Died
}

\author{
Jordan Nojkov* \\ University Clinic of Anaesthesiology, Faculty of Medicine, Ss Cyril and Methodius University of Skopje, Vodnjanska 17, 1109 \\ Skopje, Republic of Macedonia
}

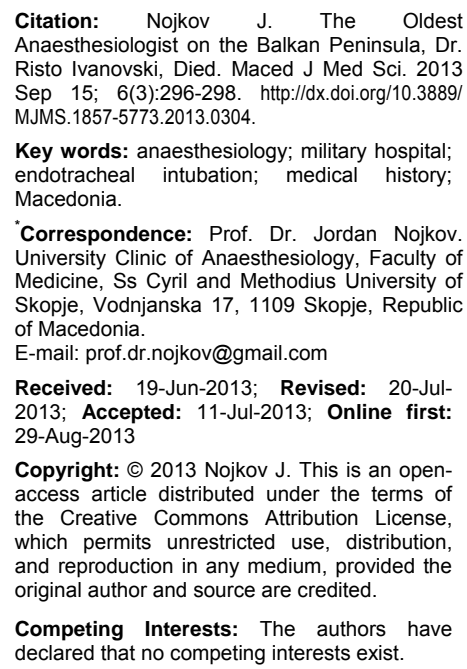

"Correspondence: Prof. Dr. Jordan Nojkov. University Clinic of Anaesthesiology, Faculty of Medicine, Ss Cyril and Methodius University of Skopje, Vodnjanska 17, 1109 Skopje, Republic of Macedonia.

E-mail: prof.dr.nojkov@gmail.com

Received: 19-Jun-2013; Revised: 20-Jul2013; Accepted: 11-Jul-2013; Online first: 29-Aug-2013

Copyright: ๑ 2013 Nojkov J. This is an openaccess article distributed under the terms of the Creative Commons Attribution License, and reproduction in any medium, provided the original author and source are credited.

Competing Interests: The authors have declared that no competing interests exist.

\begin{abstract}
Dr. Risto Ivanovski died on 17 of June 2013 in his 100-th year of life. He was the first anaesthesiologist in Republic of Macedonia and one of the founders of modern anaesthesiology in ex-Yugoslavia. He was born in Prilep, Macedonia. He started to make his way in the field of anaesthesiology in 1946. Then, Yugoslavia, as a part of the antifascist coalition, received aid in medical personnel and equipment through UNRRA. Dr. Patrick Shackleton, and Dr. Rasel Davies from Great Britain educated the first group Yugoslav doctors in the field of anaesthesiology. Then, the Army sent him to organize the anaesthesiology service at the Military Hospital in Zagreb, but because he was the only one anaesthesiologist in Croatia, numerous well-known surgeons addressed him to work together in different hospitals in Zagreb, Osijek and Rovinj). From 1954, Dr. Ivanovski worked at the Military Hospital in Skopje. He was the teacher of the first generation of Macedonian anaesthesiologists. In 1959 he was elected as an Associate Professor at the Medical Faculty in Skopje. He was also a visiting anaesthesiologist in Prishtina, Kosovo. Dr. Risto Ivanovski was the first president of the Macedonian Society of Anaesthesiology founded in 1962. His professional opus contains about 20 works where he spoke about current problems of his time; the beginnings of endotracheal intubation, the use of Viadril cyclopropane and plasma expanders, immersion hypothermia as an addition to general anaesthesia in high-risk patients, organization problems of anaesthesiology services in war etc. Dr Risto Ivanovski left numerous admirers. The generations that followed his time, respect his efforts and work.
\end{abstract}

Dr. Risto Ivanovski died on 17 of June 2013 in his 100-th year of life. He was the first anaesthesiologist in Republic of Macedonia and one of the founders of modern anaesthesiology in exYugoslavia (Fig. 1).

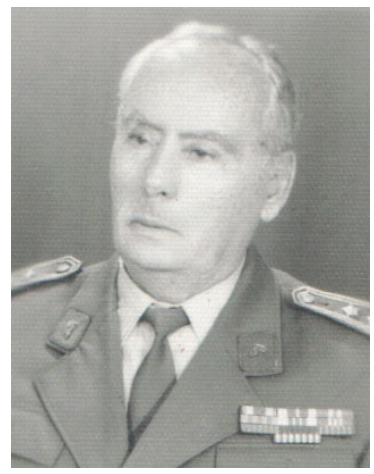

Figure 1: Dr. Risto Ivanovski (1914-2013), first anaesthesiologist in Republic of Macedonia.
He was born in Prilep, in the far 1914. He completed his elementary education in his native town, and he graduated at the Faculty of Medicine in Belgrade in 1942. After the liberation of Belgrade, he applied to be a volunteer in the Yugoslav People's Army, which sent him as an epidemiologist in the First Army (Fig. 2).

He started to make his way in the field of anaesthesiology in 1946. Then, Yugoslavia, as a part of the antifascist coalition, received aid in medical personnel and equipment through UNRRA (United Nations Relief and Rehabilitation Administration) in order to be able to help to the numerous and badly treated war injuries that led to disabilities of different kinds in many young people. Dr. Patrick Shackleton, and Dr. Rasel Davies from Great Britain were among the well-known anaesthesiologists who came to Yugoslavia from the western countries. Therefore, the 
education of the first group of Yugoslav doctors in the field of anaesthesiology started at Prof. Arneri's Clinic for Plastic Surgery in Belgrade. In this group there were Dr. Sever Kovachev and Dr. Mile Jovanovic, the founders of anaesthesiology in Serbia, and Dr. Risto Ivanovski, the founder of anaesthesiology in Macedonia and Croatia [1, 2].

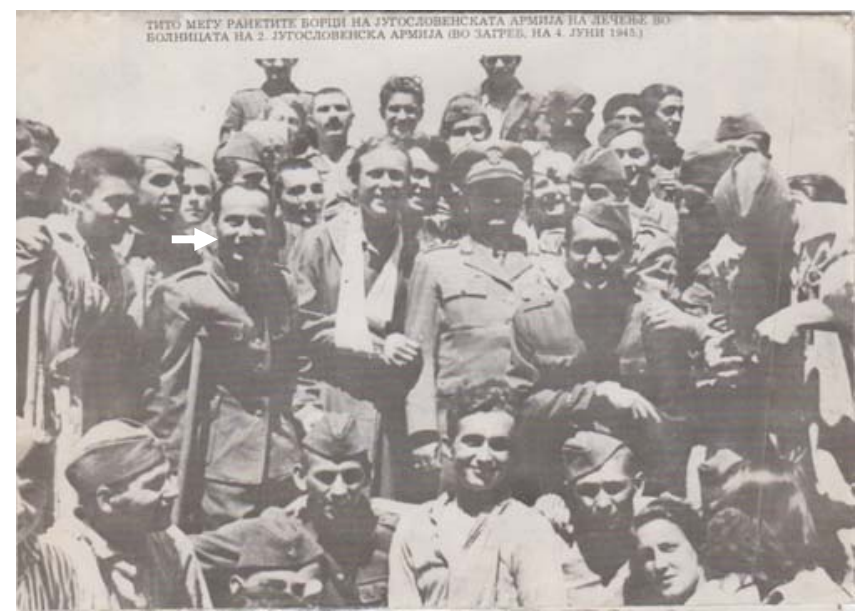

Figure 2: Dr. Risto Ivanovski (arrow) with the Marshal Josip Broz Tito. He was wounded in the final operations of the Yugoslav Army in the Second World War (June 4, 1945).

Dr. Risto Ivanovski'e life path took him to Croatia. The Army sent him to organize the anaesthesiology service at the Military Hospital in Zagreb. Dr. Ivanovski, himself, used to say when he remembered: "Since I was the only one anaesthesiologist in Croatia, numerous well-known surgeons addressed to me. I worked together with Prof. Oberhofer, who was then an assistant, but an excellent surgeon for heart operations. We used to work in the afternoons and during nights. We operated "blue children" (Tetralogy of Falot, Ductus Botali persistens, mitral stenoses, operations on oesophagus and lungs). I collaborated with Prof. Rizner (a neurosurgeon) at "Rebro" Hospital, with Prim. Florschic at "Josip Kajfers" Hospital, with Prim. Dr. Gotlib, well-known surgeon for the Croatian surgery at "Mladen Stojanovic" Hospital. I also worked at the Orthopedic Hospital in Rovinj, as well as in the hospitals in Rijeka and Osijek" [3].

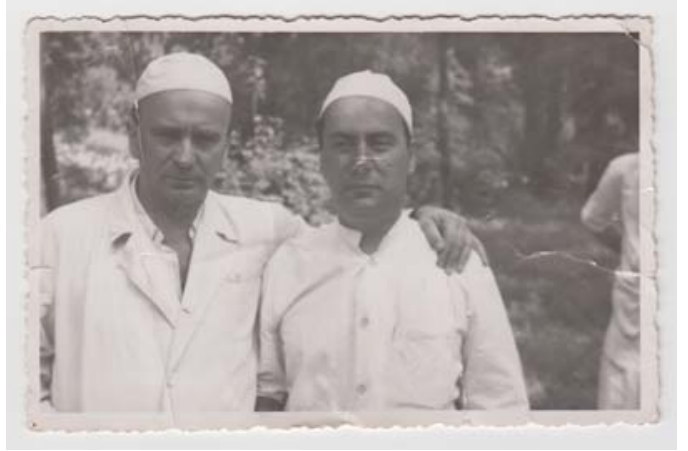

Figure 3: Dr. Risto Ivanovski (right) at the Military Hospital in Skopje with Dr. Gindzberg (left), 1961.

From 1954, Dr. Ivanovski worked at the Military Hospital in Skopje, where he was sent together with Dr. Gindzberg, a superb thoracic surgeon, in order to organize the contemporary surgical and anaesthesiology service (Fig. 3, Fig. 4). For this period of his life, he said: "Then, several good surgeons were present at the Military Hospital, namely Dr. Pakic, Dr. Pishat, and Dr. Bedekovic and the thoracic and abdominal surgery started to work. The thoracic patients were mainly ill from tuberculosis and they needed thoracoplastics, lobectomies and pulmectomies. All of them were high-risk patients, so I had to use new methods for that time, for example "underlining narcosis with Laboret's cocktail and/or immersion hypothermia. In those years we had the biggest number of anaesthesia procedures in hypothermia in Yugoslavia...".

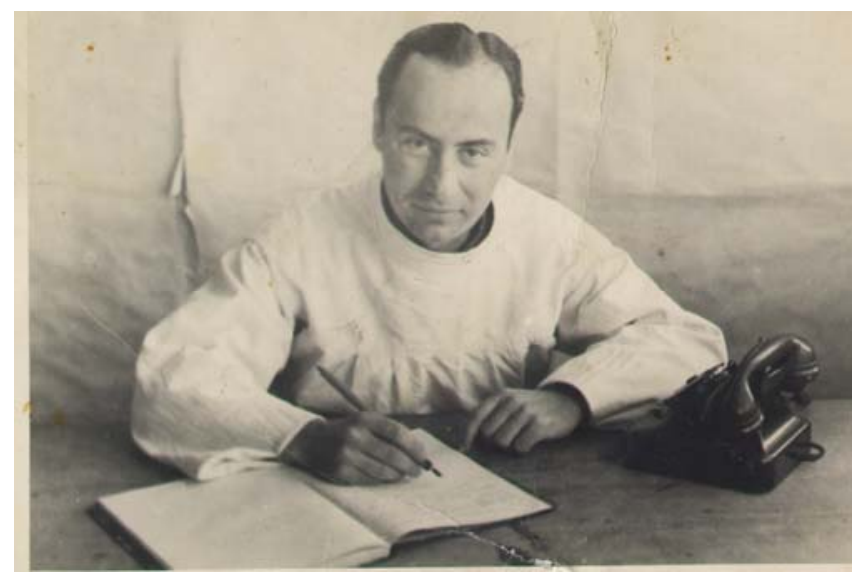

Figure 4: Dr. Risto Ivanovski in his office at the Military Hospital in Skopje, 1961.

In Macedonia, Dr. Ivanovski was the teacher of the first generation of Macedonian anaesthesiologists (Dr. Balabanov, Dr. Nikola Serafimov and others). He also organized courses for medical technicians - anaestheticians, who were the main supporters of the anaesthesiology activity. In 1959 he was elected as an Associate Professor at the Medical Faculty in Skopje and participated in the education of anaesthesiology in the framework of the subject of surgery (Fig. 5). He was also a visiting anaesthesiologist in Prishtina, Kosovo. He educated medical technicians during anaesthesiology courses in Skopje, and these were very important for the beginning of the modern anaesthesiology in Kosovo.

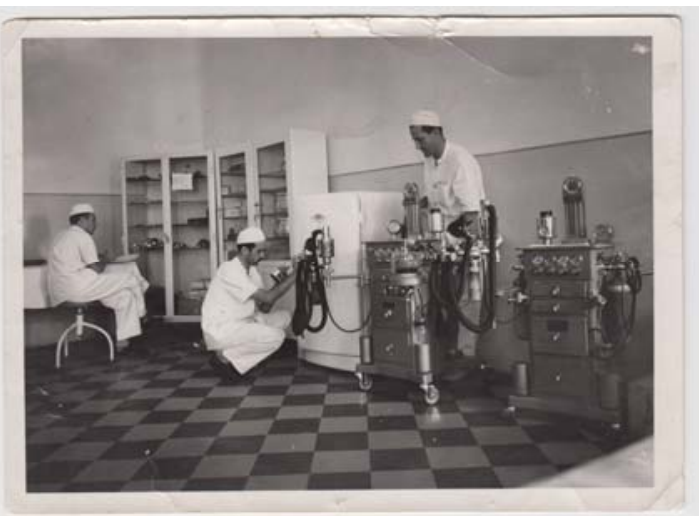

Figure 5: Department of anaesthesiology at the Military Hospital in Skopje, 1962. 
From 1954 up to his retirement in 1978, he was permanently active as a primarius and a colonel. As the Head of the Department of Anaesthesiology and Intensive Care he participated in the equipping the new Military Hospital in Skopje. A Society of Anaesthesiology at the Macedonian Medical Association was for the first time founded in 1962, and he was its first President [4] (Fig. 7).

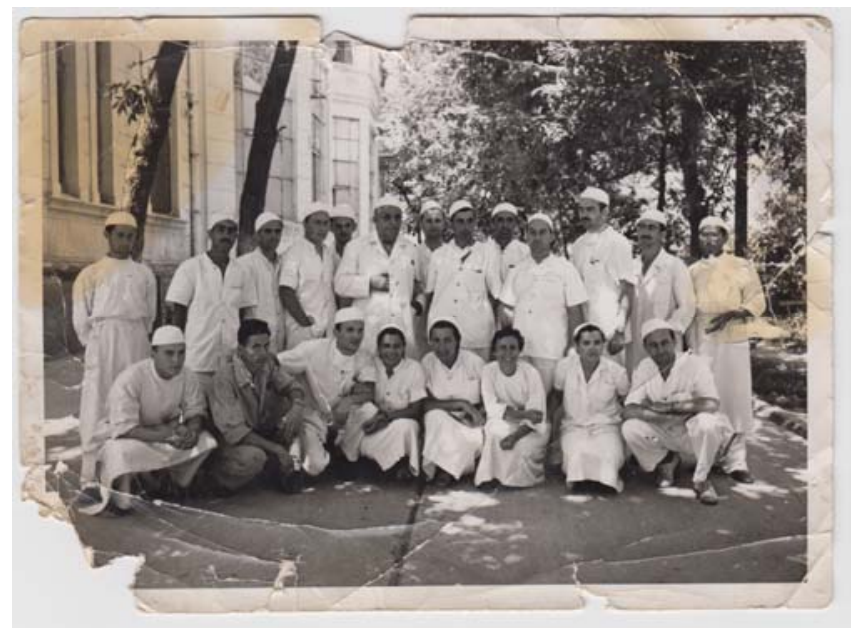

Figure 6: The staff at the Anaesthesiology Department at the Military Hospital in the old biding, 1962.

Besides his enormous work in difficult times and lack of professionals and equipment, Dr. Ivanovski found time for professional education and scientific and research work. He visited Great Britain (London and Edinburgh) and Denmark, and he stayed for a longer period in Algeria before his retirement.

His professional opus contains about 20 works where he spoke about current problems of his time; the beginnings of endotracheal intubation, the use of Viadril, cyclopropane and plasma expanders, immersion hypothermia as an addition to general anaesthesia in high risk patients, organization problems of anaesthesiology services in war and peace times etc $[5,6]$.

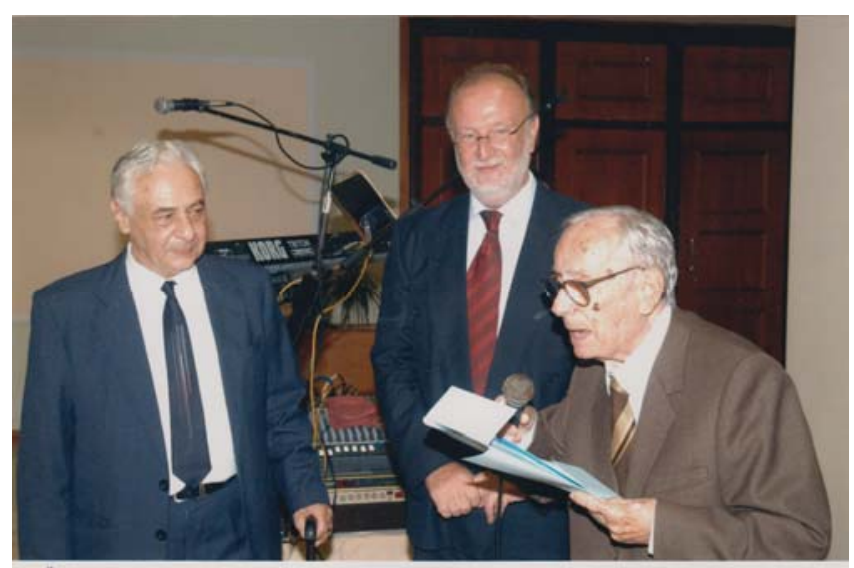

Figure 7: Dr. Risto Ivanovski (right) with his son (left) and Prof. Dr Jordan Nojkov (middle) at the 3rd Congress of Anaesthesiology in the Republic of Macedonia (2005).
We, the anaesthesiologists of the generations that followed his time, respect his efforts and work a lot. Dr. Risto Ivanovski was the honorary guest on all Congresses in ex-Yugoslavia, and on the four Congresses of Anaesthesiologists in Macedonia. Although in very old age and life destiny that did not spare him of great stresses (namely in 1963 he lost his wife and daughter in the horrible Skopje earthquake, and he also lost his second wife (Fig. 8), Mira, about ten years ago), he always found time to speak with young colleagues and to keep contacts with persons who worked or still works at the anaesthesiology department of the Military Hospital. He joyfully repeated the fact that once he had started alone, and that now in the XXI century, we are more than 200 anaesthesiologists.

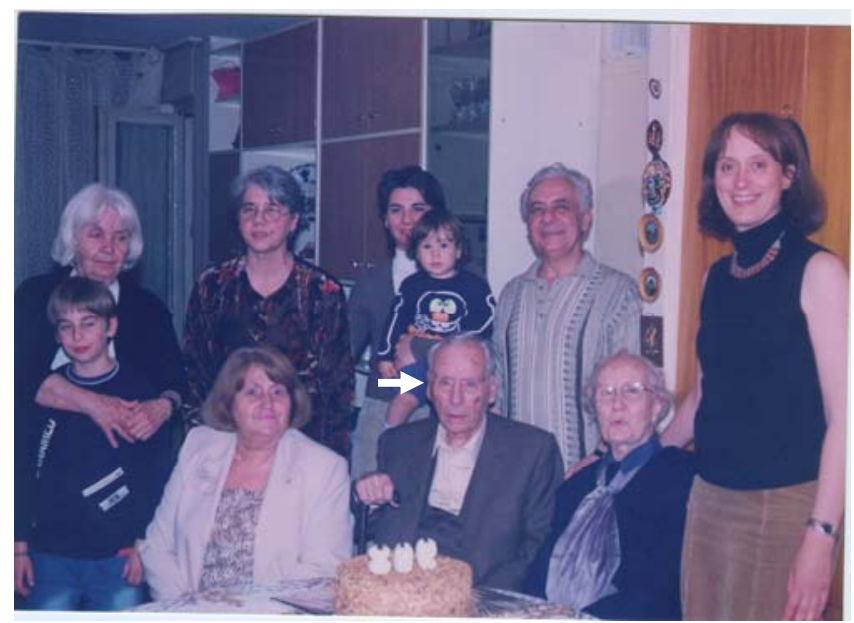

Figure 8: Dr. Risto Ivanovski (arrow) with his family on his 90th birthday, 2004.

Dr. Risto Ivanovski left numerous admirers behind him and a family of his son and grand children, who took care of him until the last day of his life.

\section{References}

1. Davies $P$. Note on the history of anaesthesia in Yugoslavia. Anaesthesiologia lugoslavica. 1989;14(5-6): 5-8.

2. Kovacev S. Prvi ucenici na glavnoj vojnoj bolnici u Beogradu. Anaesthesiologia lugoslavica. 1989;14(5-6):8-10.

3. Begovic-Sisul E, Cindric-Stancin M, Ribaric Lj. Development of Anaesthesiology and Intensive Care in Rijeka. Acta Fac Med Flum. 2000;25(1-2):79-83.

4. Dzochkov J. Prv anesteziolog vo Makedonija. Vox Medici, Скопје. 2007; 6:32-34.

5. Ivanovski R, Mladinic I, Scekic M. (1969). Nase iskustvo sa primenom hipotermije u hirurgiji. Anaesthesiologia lugoslavica. 1969;1(1):49-57.

6. Ginzberg E, Ivanovski R, Vajs E. Primena hipotermije u plucnoj hirurgiji. Vojnosanitetski pregled. 1959;11/59, Beograd. 